\title{
Key features of intra-EU labour mobility and its impact from a sending country perspective: Addressing the consequences in Hungary*
}

\author{
KLÁRA FÓTI ${ }^{1 *}$ (1) and TIBOR TAKÁCS ${ }^{2}$
}

\footnotetext{
${ }^{1}$ Social Policies Unit, European Foundation for the Improvement of Living and Working Conditions, Dublin, Ireland

${ }^{2}$ Department of Statistics, Corvinus University of Budapest, Budapest, Hungary
}

Received: 26 November 2019 • Revised manuscript received: 30 April 2020 • Accepted: 02 May $2020 \bullet$

Published online: 22 June 2020

(c) 2020 The Author(s)

\begin{abstract}
The main characteristics of intra-EU labour mobility are well documented. There is less focus, however, on the pattern of mobility of the East European (EU-13) EU-mobile citizens. This group constitutes more than half (57\%) of all the EU movers and show, to some extent, other features than the rest of the EU mobile citizens (EU-15). The first part of this paper gives a brief overview of some key demographic and labour market characteristics of the East European mobile citizens in the most important destination countries. The perspectives of the sending countries are not analysed frequently enough, and thus the second part of the paper focuses on this issue in the case of Hungary, by asking to what extent the serious labour shortages, ensuing from the outflow of Hungarians, could be compensated by the recent increase of immigration of third country nationals. Using OECD data, the paper quantifies the balance of labour gains and losses for Hungary and compares this with Czechia, Poland, and Slovakia. The analysis concludes that despite the substantial recent inflow of third country nationals into Hungary, it remains to be seen whether this has a real substitution effect for the lost domestic labour force.
\end{abstract}

\section{KEYWORDS}

labour mobility, labour markets, labour loss, labour gain

JEL CODES

J61, J62, 015

*Corresponding author. E-mail: Klara.Foti@eurofound.europa.eu.

* The views expressed in this article are those of the authors, and do not reflect those of the organisations which the authors represent. 


\section{INTRODUCTION}

Even if the recent debates both at the EU and member state level were dominated by the consequences of the large refugee inflow of 2015, the extent, pattern and the impact of intra-EU mobility is still high on the agenda. The consequences are discussed within political debates in individual member states (both in the receiving and sending countries), focussing on a wider impact of intra-EU mobility: not only on the labour market, but also its social dimensions in the key destination countries (see e.g. Eurofound 2015).

The perspectives of the sending countries are, however, also important. The free movement of persons guaranteed in the EU has led to labour shortages in most of East European (EU-13) member states. There is still a significant difference in the level of economic development and correspondingly of wages compared to the developed economies of the EU, which stimulates outward mobility from the region. Linked to emerging labour shortages, the decision makers in these countries have eased the opportunities for the immigration of workers primarily from outside the EU. This means that there could be a substitution effect, i.e. these countries can experience workforce gains as well.

After providing some details of the general labour market features of intra-EU mobility focussing on the EU-13 workers, the second part of this paper analyses some impacts of mobility on the labour market of a sending country, Hungary. More specifically, it explores the balance of losses and gains deriving from mobility and a recent increase of immigration of third country nationals, respectively.

With regard to the methodology applied in the paper, the first part synthetizes the results of EU-level data, and it is also based on mainly qualitative research conducted by Eurofound on some key features of intra-EU mobility in nine important destination countries. The second part of the paper relies on a quantitative data analysis. The data are derived from migration data published by the OECD. The original sources of these data are censuses and Labour Force Surveys, which make it possible to examine and to quantify the workforce gains and losses of Hungary in a greater detail. In order to interpret the results better, the results for Hungary will be directly compared with similar results for some other East European member states (Czechia, Poland and Slovakia), based also on the OECD data.

The structure of the paper is as follows. In order to provide a theoretical background and highlight relevant findings of previous research, first a brief literature review will be given in Section 2. Then, in Section 3, some key demographic and labour-market-related characteristics of the EU-13 mobile population will be outlined, followed by the most recent employment trends of the EU-13 mobile citizens in the destination countries as well as at the EU level. The Hungarian case will be discussed in Section 4, where first the economic and labour market situation in Hungary will be outlined, followed by the results of the quantitative analysis on the losses and gains, and a comparison with the other countries of the Visegrád group (Czechia, Slovakia and Poland). Finally, conclusions will be drawn in Section 5, which also proposes some topics for further research.

\section{PREVIOUS RESEARCH AND THEORETICAL BACKGROUND}

The literature on the impacts of labour migration is extensive. Many studies analyse the pull and push factors (see e.g. Anghel et al. 2015; Gheasi - Nijkamp 2017 from the recent literature, and the references therein). Typically, workers from developing countries intend to find jobs 
in developed countries, which suggests that the most important driver of labour migration is of an economic nature, i.e. to attain higher salaries. The most obvious impact of emigration from sending countries is referred to as brain drain from, or brain waste for these countries, since they bore the cost of education, which the receiving countries then benefit from. In the past couple of decades, several studies challenged this simplified approach, emphasizing the role of remittances, including so-called social remittances that may have positive impacts on the sending countries. Some authors suggest that such positive impacts may compensate the brain loss: for example, Okólski (2012) considers labour migration indispensable for modernization. The financial remittances may have significant positive impacts in the sending countries even in short term. As they are measured by the statistical services, these positive impacts - primarily on reducing poverty and inequality - are quantified and analysed by several papers (see e.g. Azizi 2019). The social remittances include ideas, behavioural practices, new skills and knowledge, changing norms, values and attitudes etc. that may have further positive impacts in the migrants' home countries. These impacts, however, can hardly be measured, the different studies and papers analyse them primarily in a qualitative, theoretical and less empirical way (Pires 2015; Rapoport 2017; Sandu 2010). Anghel et al. (2015) state that all these remittances can be 'equilibrating mechanisms between sending and receiving countries'. However, the social remittances have only indirect impacts and mostly only on the mid- and long term. Several papers underline that the positive impacts of social remittances may depend on certain circumstances or these impacts might be negative (Bénassy - Brezis 2013; Croix - Docquier 2012). Grabowska et al. (2017) remarked that it is difficult to assess and separate the impacts of social remittances from the general impacts of globalization. The evaluation of social remittances has policy implications as well. Brock and Blake (2015) confront two opinions. If the positive impacts of social remittances counterweigh the brain loss, then emigration should not be restricted (Blake), while other policies may allow at least temporary restrictions (Brock) to avoid short term negative impacts.

The Eastern enlargement of the EU resulted in a special situation. The Western member states opened their labour markets within a short period of time. The practice has proven what the less liberal theorists predicted: at least in the short term, the impacts on the less developed sending countries have been rather negative. The economic pull factor, i.e. the relatively higher wages and living standard attracted many labour migrants to the developed Western EU members, resulting in brain loss and severe labour shortages in the sending countries. The most painful direct impact, which, during the COVID-19 pandemic, became particularly visible, is the emigration of health professionals. It is understandable that a large share of the literature dealing with labour migration discusses this problem (Botezat - Ramos 2020; Dohlman et al. 2019; Saluja et al. 2020). A further challenge is the skill mismatch of migrants, which can be considered as an additional brain loss. In order to analyse the impacts, reliable data are needed. Unfortunately, the statistical services cannot always realistically follow labour migration, and the mirror statistics are often inconsistent. However, several studies conducted by Eurofound (among others) provide valuable information, on which such analyses can be based. Results of one of these studies will be presented in the first part of this paper, which includes the mobile citizens' demographic characteristics, their employment rate, educational attainment level, and the pattern of occupation categories. The second part is based on an update of the OECD data, which are suitable to assess the brain loss of the East European sending countries of the EU. A proxy will be developed, which also takes brain gain into account, as a large amount of workers from third countries partly substituted the labour 
shortage in these countries. The situation of Hungary will be analysed in detail in comparison with some other new EU members in the region (Czechia, Poland and Slovakia).

The Central and Eastern European countries, including Hungary, have been sending countries for more than a century. The literature of the Hungarian workers' mobility is relatively scarce for a lack of appropriate data and information. Therefore, some papers basically rely on special own surveys. Golovics (2019) gives an overview of the main driving forces of migration, and about the relevant literature, stating that macroeconomic aspects of migration have been rarely researched in Hungary, and most papers focus rather on sociological aspects. Moreh (2015) relies both on public data and also employs qualitative information from an ethnographic fieldwork in London conducted in 2013. This paper presents some socio-demographic and labour market characteristics of Hungarian emigrants in the United Kingdom, which became a new destination country for Hungarian mobile workers after the country had joined the EU. The paper found, however, that more than half of the newly arrived migrants do not stay in the country for the longer term. Gödri (2016a) analysed the migration potential and motives by statistical methods based on a special survey, with a large $(n=1,464)$ sample of $18-40$ years old Hungarian people (the sample was representative by gender, age, educational attainment level and settlement type). The results showed that the main motives included family and labour market status (single, inactive, unemployed) and unfavourable financial conditions. Similar results have been published by Józsa and Vinogradov (2017) as well. Hárs and Simon (2017) analysed the return rate of Hungarian mobile workers by region and by profession. Gödri (2016b) focused on the integration of immigrants to Hungary based on the data of the National Census of 2011, discussing also the labour market participation of immigrants among which the employment rate proved to be higher and the unemployment rate lower compared to the entire population. This may indicate that foreign workers in Hungary can contribute to substituting at least a part of the Hungarian mobile workers who left the country. This is one of the focuses of this paper, where the authors use more up-to-date data.

\section{CHARACTERISTICS OF EAST-EUROPEAN MOBILE WORKERS AND THEIR LABOUR MARKET PERFORMANCE IN KEY DESTINATION COUNTRIES}

This chapter synthesises the key findings of a research project conducted in Eurofound in 2014/ 2015 and entitled "The social dimension of intra-EU mobility: Impact on public services". The research focused on experiences in nine key destination countries: Austria, Denmark, Germany, Ireland, Italy, the Netherlands, Spain, Sweden and the UK. As its title suggests, the project focused mainly on the take-up of benefits and social services by mobile citizens from 11 Central and Eastern European member states (EU-11) ${ }^{1}$ citizens in the above host countries, compared to

\footnotetext{
If these counties are analysed as a group (i.e. EU-level data, mainly from Eurostat), they are called EU-13 since they contain also Cyprus and Malta which joined the EU at the same time as most Central and Eastern European countries, in 2004. In the Eurofound study, however, the country studies often contained data only for the citizens coming from the Central and East-European member states. If Croatia (which joined later, in 2013), was also included, the study mentioned the group of EU-11. However, earlier data, which did not include Croatia, just the Central and East-European member states, i.e. those which joined in 2004 and 2007 respectively, refers to this group as EU-10. Sometimes this group was further divided into EU-8 and EU-2, differentiating the countries which jointed in 2004 and 2007.
} 
the native population and other citizen groups. This topic, is, however, closely linked to some features of labour market performance and position of these citizens.

The methodology of the Eurofound study was a combination of statistical analyses of country data and qualitative information from the host countries. The country reports, prepared for each host country, contained data and information not only on the socio-economic profiles of the mobile citizens from the Central and Eastern European member states (such as educational attainment, age, gender), but also some key indicators on their labour market performance, i.e. employment and unemployment rates, sectorial distribution, and some information on their income (where data were available). On the other hand, the country reports provided qualitative information on different rules, which determined the take-up of social services and allowances (data on these issues were also provided if they were available, and sometimes some estimates were made as well).

\subsection{Demographic characteristics}

According to Eurostat data, out of the 6.357 million EU-13 citizens of working age living in the EU-15 countries, close to 6 million (5.995 million) resided in those nine destination countries this article focuses on. The country studies, prepared for the Eurofound research project (Eurofound 2015) confirmed that the EU mobile citizens from the Central and East-European countries are younger than the native population, and the proportion of working age population among the EU mobile citizens is higher than among the native people. For example, the average age of the natives in the Netherlands and Spain was above 40, whereas that of the EU mobile citizens was around 30. Similarly, in the UK, according to estimates, the average age of the UK citizens was close to 40, whereas among the EU0 mobile citizens it stood around 28. Among Polish people living in Germany, the primary working age group was larger than $50 \%$ (with those between 25 and 35 years making up 26\%, and those between 35 and 45.25\%). In Denmark, the largest age group among the Central and Eastern European EU mobile citizens was between 16 and 30 years, their proportion being $46 \%$, whereas the same figure was $17 \%$ for the natives (for more data on Sweden, Ireland, Italy and the UK, see Eurofound 2015: 15-17).

The gender composition seems balanced in most countries. There is one notable exception, where women's proportion was found consistently high: in Italy it stood at around 55-57\%. Examining the age composition of women revealed that among them the proportion of those aged 40 and over is high; more than half among Bulgarian women, above $40 \%$ among Polish women and close to $40 \%$ among Romanians (Eurofound 2015: 18). It was found that among the Central and East-European mobile workers, "men tend to work in manufacturing and construction, whereas women typically provide home care and elderly assistance. The fact that, despite the crisis, the share of women in this group has not changed reflects a persistently high demand for care workers" (Eurofound 2015). Italy is a special case also because here the majority of the EU mobile workers came from the Central and East-European member states.

\subsection{Labour-market-related characteristics of the EU mobile population from the East-European member states}

Even if the age composition could provide an explanation for the generally higher employment rate, it is important to reveal the differences between educational backgrounds of immigrants. 
Although the data cannot be directly compared across the countries (see the notes below the table), there is a clear tendency. For example, the (relatively) newly arrived EU citizens mainly have medium level educational attainment. This is not surprising - not only has this been concluded by previous research (see for example Eurofound 2015), but this is usually also true for the natives - with the exception of the UK. ${ }^{2}$ At the same time, it is interesting to see that in all the three traditional immigration countries (Austria, Sweden ${ }^{3}$ and the UK), the proportion of the highly educated EU10/8 citizens are higher than that of the natives. As can be seen from Table 1, in the UK, among all the immigrants, those who are well qualified have the highest proportion vis-à-vis all the other groups. The proportion of highly qualified immigrants is much higher than that of the natives (46 vs. 24\%). Apart from the influence of high qualification of EU immigrants (who make up 35\% of all the immigrants), the high proportion may reflect partly the fact that many foreign (third country) students stay in the UK, and partly (somewhat related to this) that selective migration policy may also play some role.

At the same time, it is also clear that for countries where reliable data are available for within-country comparison across the various groups (unfortunately this is not entirely the case for Sweden - see the notes below Table 1), and where there is a sizeable EU-14 community (i.e. EU-15 citizens minus those of the host country), their educational attainment is higher than that of the EU citizens from Central and Eastern Europe. In Austria the proportion of the highly educated among the EU-14 is larger than that of the two groups of the more recently joined EU citizens, being 37\% (whereas for the EU-10 and EU-2 these proportions are 23 and 20, respectively); in the UK, the proportion of the EU immigrants having high education is higher than in the case of the EU- 8 group ( $45 \mathrm{vs.} 38 \%$ ). This pattern can also be observed at the EU level: "For EU-15 movers, the highly educated group prevails [...] For EU-13 movers, however, it is the group with medium-level education that has the highest share compared to nationals in the destination countries with the same level of education" (European Commission 2018).

While the Central and Eastern European EU mobile citizens are generally well qualified, this pattern is not reflected in their occupational distribution. For example, in the UK the EU immigrants have the lowest share in the "professional" category $(18.2 \%$, whereas the respective proportion of the UK-born is $20.0 \%$, and that of all the immigrants is $22.9 \%$ ). At the same time, their share is the highest in the elementary occupations and processing categories ( 31.9 vs. $15.3 \%$ and 24.8\%, respectively; Eurofound 2015: 6). Similarly, in Sweden, the proportion of those EU10 citizens who work in elementary occupations is higher than that of the natives (Kullander 2014). In Denmark, the proportion of those who have tertiary education, but work in elementary occupations is much higher among the EU-10 citizens than among the natives (Lunde Rasmussen - Kuhn 2014).

\footnotetext{
${ }^{2}$ The UK is a special case, and not only due to its different education system. Part of the explanation could be that this is the country where many of the UK-born citizens themselves have in fact a migration background. They are in a more vulnerable situation than the natives, which could be reflected, inter alia, also in their low educational attainment.

'While the data for the EU-10 citizens are not entirely reliable in Sweden, previous research has also shown that those people who were born in the EU-12 countries (i.e. in the new member states at that time), and who are at work, have overall higher educational attainment than the natives (Kullander 2014: 15).
} 
Table 1. Educational attainment by three major categories and by groups of EU-mobile citizens in the selected host countries (\%)

\begin{tabular}{|c|c|c|c|c|}
\hline & & Low education & Medium education & High education (tertiary) \\
\hline \multirow[t]{4}{*}{ Austria } & Natives & 24 & 61 & 15 \\
\hline & EU14 & 9 & 54 & 37 \\
\hline & EU10 & 14 & 63 & 23 \\
\hline & EU2 & 20 & 60 & 20 \\
\hline \multirow[t]{3}{*}{ Italy $^{d}$} & Natives & 32 & 47 & 19 \\
\hline & EU nationals ${ }^{c}$ & 27 & 60 & 11 \\
\hline & Third country nationals & 51 & 38 & 10 \\
\hline \multirow[t]{2}{*}{ Spain $^{a}$} & Natives & 22 & 46 & 16 \\
\hline & EU10 & 11 & 62 & 9 \\
\hline \multirow[t]{3}{*}{ Sweden $^{b}$} & Natives & 23 & 51 & 26 \\
\hline & EU14** & 26 & 41 & 27 \\
\hline & EU10 & 12 & 42 & 33 \\
\hline \multirow[t]{3}{*}{$\mathrm{UK}^{\mathrm{e}}$} & UK-born & 43 & 33 & 24 \\
\hline & EU immigrants & 13 & 42 & 45 \\
\hline & EU8 immigrants & 8 & 53 & 38 \\
\hline \multicolumn{2}{|c|}{ All immigrants } & 18 & 36 & 46 \\
\hline
\end{tabular}

Sources: Eurofound (2015) country case studies, with the exception of the UK; for the UK: Wadsworth (2017: 4). Notes: Based on ISCED categories, defined as follows: ISCED 1+2: Low education; ISCED 3+4: medium, and ISCED4 +5: high education; data on Spain are indicative only, due to missing data (18.7\% of the data are missing for the EU-10, $15.7 \%$ for EU-27 and $15.9 \%$ for natives). In countries with missing data (Spain and Sweden in case of the EU10), the sum of the percentages may not be 100.

a In Spain no ISCED categories were indicated, so in the label of "Low education", the following categories were included: illiterate; incomplete primary education, primary education; for "Medium education": Secondary education; "High education": Tertiary education.

${ }^{\mathrm{b}}$ In case of the EU-10, the educational attainment of a relatively high proportion is unknown: 13.8 (this share in EU14 is $6.4 \%$ and among Swedes: $0.7 \%$ only).

${ }^{\mathrm{C}}$ The data in Italy refers to EU nationals only, but because $90 \%$ of them is made up of EU-10 citizens, this data could be regarded as proxy for EU-10.

${ }^{\mathrm{d}}$ Data on ISCED 4 is not available.

${ }^{\mathrm{e}}$ In the UK, no ISCED categories were indicated. Instead, the data are based on the age of leaving education. So the categories of educational attainment are as follows: Low education: 16 or under; medium: 17-20; high: 21 or older. EU-14 refers to EU-15, except the native country. EU10 refers to the countries which joined the EU in 2004. 


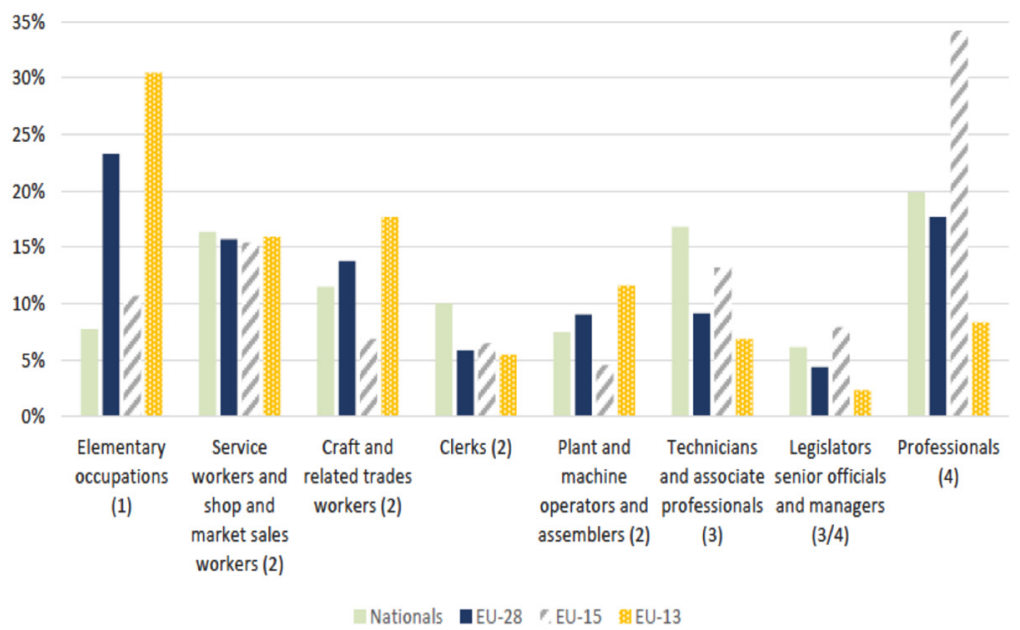

Note: Occupations are sorted according to the corresponding skill levels (number in brackets), where 4 is the highest skill level, 1 is the lowest (ISCO).

Fig. 1. Main occupation categories by EU country groups (EU-28, EU-15 and EU-13). Source: European Commission (2018: 75)

The dominance of employment of EU-13 citizens in low occupational categories is confirmed by aggregate EU level data. As can be seen from Fig. 1, EU-13 mobile workers are heavily overrepresented in elementary occupations (the difference between EU-15 and EU-13 being about 20 percentage points). Their proportion is the highest in the "plant and machine operators" and the "craft and related trades workers" categories, but the difference is smaller (with regard especially to the latter category, these occupations may require medium level skills). At the higher end, especially in those occupations requiring the highest skills, they are even more underrepresented than they are overrepresented in the lowest category, since here the difference may reach about 25 percentage points.

The sectorial pattern also reflects the dominance of low occupational outcome of the new EU mobile workers, since most of them are employed in sectors which are known to employ workers in occupations requiring low skill level. Such sectors (which are also known as employing many migrant workers) are construction, agriculture, transport, health care, domestic care, etc. As can be seen from Table 2, in these sectors the proportions of the EU mobile workers from Central and Eastern European member states are higher than that of the natives (in the case of the Netherlands, there were no comparable data available for natives, but the figures show that the proportion of Bulgarians employed in construction and the domestic help sector is especially high, being $33 \%$ in each sector).

In the UK, according to more recent data, more immigrants, in particular EU-8 mobile workers, are employed in the health, hotel and restaurant sectors than in other sectors. With $10 \%$ of the total workforce employed in the hotel sector, the proportion of EU workers is higher than the total share of the UK workforce employed in the sector (around 6\%; see Wadsworth 2017: 5). 
Table 2. Sectorial pattern of employment of the EU10 citizens (selected countries and sectors, \%)

\begin{tabular}{|c|c|c|c|c|c|c|c|c|}
\hline Host countries & $\begin{array}{l}\text { Citizenship } \\
\text { groups }\end{array}$ & Construction & Agriculture & Industry & Transport & Health & $\begin{array}{l}\text { Domestic help and } \\
\text { cleaning }\end{array}$ & Social security \\
\hline \multirow[t]{2}{*}{ Spain (2013) } & Romanians & 13 & 13 & 11 & & & & \\
\hline & Natives & 6 & 4 & 15 & & & & \\
\hline \multirow[t]{3}{*}{ Germany (2011) } & Poles & 18 & 2 & 20 & 19 & & & \\
\hline & Romanians & 10 & 2 & 24 & 20 & & & \\
\hline & Natives & 7 & 1 & 20 & & & & \\
\hline \multirow[t]{2}{*}{ Sweden (2010) } & EU12 & 11 & 3 & 13 & & 19 & & \\
\hline & Natives & 7 & 2 & 14 & & 16 & & \\
\hline \multirow[t]{2}{*}{ Denmark (2013) } & EU10 & 5 & 15 & 17 & 6 & & & 6 \\
\hline & Natives & 5 & 2 & 12 & 5 & & & 20 \\
\hline \multirow{2}{*}{$\begin{array}{l}\text { The Netherlands } \\
\text { (2011) }\end{array}$} & Poles & 28 & 13 & 28 & & & 8 & \\
\hline & Bulgarians & 33 & 2 & 5 & 9 & & 33 & \\
\hline
\end{tabular}

Source: Eurofound (2015) country studies. 


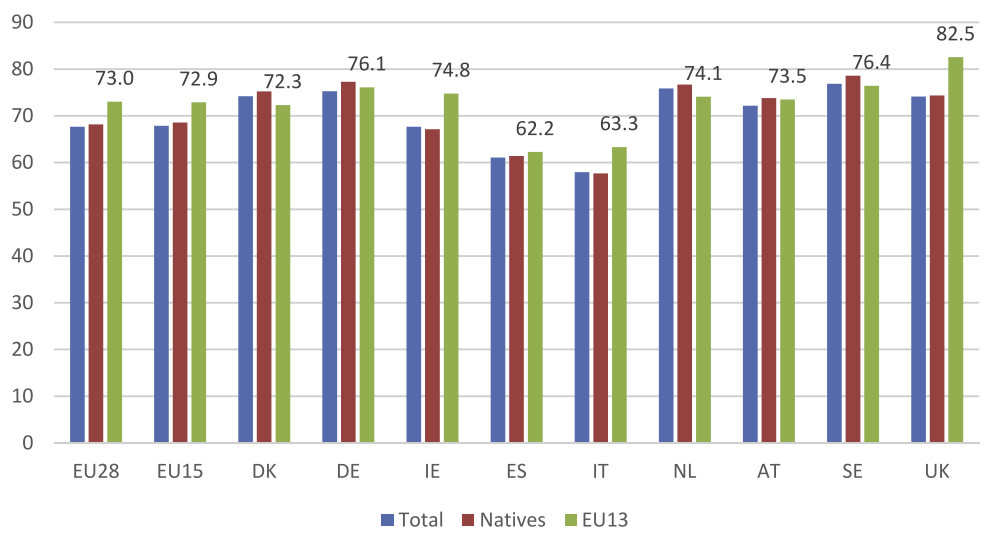

Note: * Due to country groupings in Eurostat aggregate statistics, Cyprus and Malta are also included in this group.

Fig. 2. Employment rate of EU-13 citizens* in the selected destination countries, compared with that of the total and native populations in 2017. Source: Eurostat

\subsection{Labour market performance - as indicated by employment rate and its trend during the post-crisis period}

As is well known and highlighted by the literature (Eurofound 2015), the employment rate of mobile EU-citizens from mainly the Central and Eastern European member states (EU-13, which includes also Cyprus and Malta) has consistently been high; in most destination countries it is even higher than that of either the natives or the total employment rate. As Fig. 2 shows, there are some exceptions though (according to data from 2017): the most notable are Germany, Austria, Denmark and Sweden. In both Austria and Germany the natives' employment rate was higher (although in Austria the difference was marginal in 2017), in Sweden the rate (76.4\%), though high, is still lower than both the total (76.9\%) and that of the natives (78.6\%), but again, the difference is not considerable.

Even if this higher employment rate is understandable due to the aforementioned composition effects (i.e. that the overwhelming majority from EU-13 countries are of working-age and they emigrated to take up employment ${ }^{4}$ ), the rate further and continuously increased during the post-crisis years, related obviously to the recovery ${ }^{5}$, as Fig. 3 shows.

With regard to individual countries (see Fig. 2), both in Ireland and in the UK, which opened their labour markets immediately after the accession of the eight new member states (EU-8) ${ }^{6}$ in 2004 (the third such country was Sweden), the employment rate of the EU-13, exceeding $80 \%$ in

\footnotetext{
${ }^{4}$ For example, in the UK, 70\% of EU immigrants indicated work-related reasons for coming (Wadsworth 2017).

${ }^{5}$ Although, the unemployment rate of the EU-13 mobile citizens was one percentage point higher than that of the other groups (EU-15 and natives), being 9\% (European Commission 2018: 70).

${ }^{6}$ The four Visegrád countries, i.e. Czechia, Hungary, Poland and Slovakia, plus Slovenia, and the three Baltic states, Estonia, Latvia and Lithuania.
} 


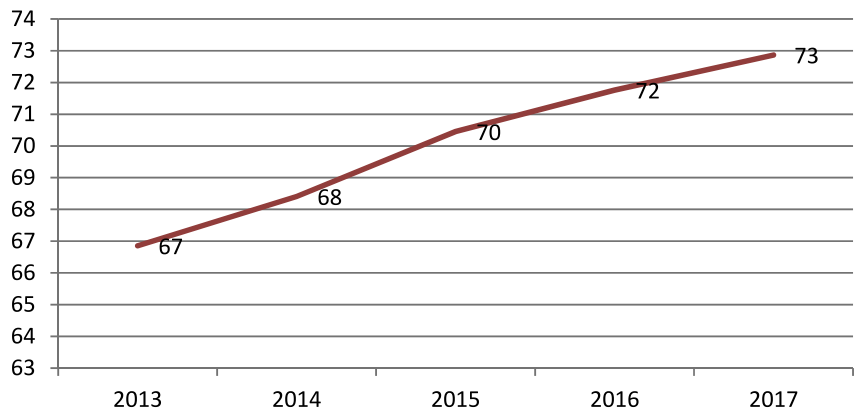

Notes: See notes to Figure 1. There was a break in the time series in the case of Denmark in 2016 and 2017 and in Ireland in 2017.

Fig. 3. Employment rate of EU-13 citizens in the EU-15. Source: Eurostat

the UK, is much higher than that of the natives. The high employment is also reflected in the fact that in 2016 the unemployment rate of the EU-8 group was the lowest, and the second lowest for EU immigrants (2.5 and 3.2\%, respectively), compared to the other groups two groups (UK-born: $3.3 \%$, all immigrants: $3.9 \%$ ). The proportion of inactive people (as well as students) is also the lowest in case of the EU-8, and the next group is the EU immigrants (Wadsworth 2017: 5).

\section{LABOUR LOSSES AND GAINS IN HUNGARY}

Intra-EU mobility had significant impacts on the Hungarian labour market, especially in the post crisis period, when all the EU-15 countries - including Austria and Germany - gradually opened their labour markets for workers from the Central and Eastern European member states. The main cause of the previous reluctance of the more affluent countries to open their labour markets had been the fear of a possible massive migration and its consequences in terms of unemployment and wages. The practice has shown that, although there was a large inflow, employees from the Central and Eastern European tended to undertake rather low-skill jobs (as shown in the previous section), and there has been no evidence of a downward pressure on wages in the main destination countries.

However, emigration of workers is a loss for the sending countries. Obviously, the impact pf this loss varies according to special characteristics and development levels of these economies. The negative impact of emigration can be mitigated by the immigration of workers from third countries. ${ }^{7}$ Since the real wage differences can be considered to be the main driving force of workers' mobility, immigrants can be expected from less developed countries, depending on the

\footnotetext{
${ }^{7}$ The literature also assumes this - see for example, Hárs (2019), who refers to Ravenstein's seminal work, The Law of Migration from 1885. At the same time, as Hárs points out, the substitution, if any, may not have an immediate effect, as a transition period may follow the outflow (Hárs 2019: 154).
} 
actual regulation and rules. We present below an attempt to quantify this substitution effect, i.e. the balance of losses and gains. The latter stems from immigration into these countries. Unfortunately, it is difficult to obtain useful data for such an analyses, and very often the migration data of the different countries are inconsistent. We have relied on recent OECD data, specifically on two modules of the OECD Migration Database: the 2015-2016 update of the Database on Immigrants in OECD countries and non-OECD countries (DIOC) and on dataset on employment, unemployment, participation rates. This means that the estimation of the balance is conservative, since the DIOC database contains information only for those mobile Hungarian workers whose destination was an OECD country.

\subsection{The economy and the labour market of Hungary in the 2010 s}

The Hungarian economy showed a W-shaped path in the $21^{\text {st }}$ century. After a deep recession in 2009, a second smaller setback happened in 2012. However, the economy has been continuously growing since then, while the unemployment rate has been decreasing: it fell below $4 \%$ at the end of 2017. In 2014, GDP per capita reached its pre-crisis level, but the recovery was slower in terms of real income per capita, which reached the 2007 level only in 2016. This indicates that there was a strong wage moderation up to 2015 that supported the increase of competitiveness. The income policy became expansive in 2016. The increase of the minimum wage between 2016 and 2020 was 45\%, while that of the so called guaranteed minimum wage (for people with at least a secondary educational attainment) was $60 \%$. The annual increase of gross wages in the government sector was around $10 \%$. This means that the wage dynamics exceeded the GDP growth rate and also the growth rate of productivity. However, this can be considered a correction after a longer period of low wages, and has not led to inflation, which remained in the target zone of monetary policy of $3 \pm 1 \%$. However, there was still a slight deflation in 2014-2015, and increasing inflation since then indicates that the economic policy is pro-cyclical. Growth has been fuelled by the accelerated use of capital transfers from the EU Structural and Investment Funds, and also from foreign direct investment (FDI), in particular in the field of automotive manufacturing, which plays a crucial role in exports. The foreign automakers receive large financial support from the state in exchange for their contribution to employment. Even if all this economic context would not imply a massive emigration of workers, the level of wages is still far below that of the more affluent EU member states. In real terms, the gap is around $40 \%$.

The Hungarian labour market has further special features. Although the three month duration of the unemployment benefit is the shortest one in the EU, there has been a public works programme directly creating jobs since 2011 . This means that the unemployed may apply for short term employment for $60 \%$ of the minimum wage per month that is paid from the central budget. These workers appear in the statistics of employed. The number of employed grew from 3.7 to 4.5 million in the period of 2010-2018, the share of workers in the public works programme fluctuates in the range of $1.5-4 \%$. About $2 \%$ of the domestically employed is registered as working abroad, but only in case of workers registered at a domestic household, expected to return within a year. The third distorting factor is that the Labour Force Survey can hardly reach the foreign-born workers in Hungary.

Labour shortage in many sectors in the wake of emigration of workers may have also been one of the driving forces of the dynamic increase of domestic real wages mentioned above. The 
number of vacant jobs was around 33,000 in 2013, i.e. in the first year of recovery. This number has been gradually increasing and exceeded 85,000 at the end of 2018 . One fifth of the vacant jobs can be found in manufacturing industries, but the rate of vacant jobs exceeds $10 \%$ in administrative and support service activities, in human health and social work activities, in public administration and defence, and in compulsory social security. Regarding occupations, the most missing ones are professionals, technicians, associate professionals and elementary occupations.

\subsection{Quantification of losses and gains}

First, the number of Hungarian born workers abroad have been estimated, but as mentioned above, only the intra-OECD mobility can be calculated using the DIOC data. The number of emigrated Hungarian workers are broken down by sex, education level, and occupation (ISCO 1 digit). Also, the number of overqualified persons is given, although this information is missing in about $40 \%$ of the cases. Both the loss and the gain have been calculated by education level. The DIOC database contains three different categories: the first one corresponds to the ISCED 1 and 2 level, the second one to ISCED 3 and 4, and all other ISCED levels belong to the third group. If the education level is missing from a data record, it is substituted by the skill level. The skill level is a classification of four groups in the ISCO nomenclature, but only three groups are applied in the DIOC database. The first corresponds to elementary occupations (ISCO one-digit category 9), the second to plant machine operators and assemblers (ISCO two-digit category 8) and the third one to all other occupations. If both data were missing, we substituted it with the ISCED 1 level when calculating either the loss or the gain. The calculations have been made for the actual working persons as well, which means that the numbers belonging to the particular groups have been multiplied by the employment rate given in the other above-mentioned modules of labour market status.

The gain from OECD and non-OECD countries has been calculated in a similar way. The level of educational attainment was complete in this case. We have not taken into account the fact that there may be an adjustment cost on this side, primarily caused by lack of the language knowledge. However, a large share of foreign-born workers are ethnic Hungarians, coming from neighbouring countries. Table 3 presents the calculated stock of losses and gains. There is loss in each category, but it is the highest in the highest educational attainment category: this is true for

Table 3. Stock of losses and gains in Hungary (2015-2016, workers)

\begin{tabular}{|l|c|c|c|c|c|c|}
\hline & \multicolumn{3}{|c|}{ Potential } & \multicolumn{3}{c|}{ Actual } \\
\cline { 2 - 7 } & Gain & Loss & Balance & Gain & Loss & Balance \\
\hline ISCED 1 and 2 & 24,873 & 42,725 & $-17,852$ & 18,342 & 28,199 & $-9,857$ \\
\hline ISCED 3 and 4 & 140,283 & 164,082 & $-23,799$ & 103,518 & 108,294 & $-4,776$ \\
\hline ISCED 5 and higher & 89,007 & 141,722 & $-52,715$ & 65,676 & 93,537 & $-27,861$ \\
\hline Total & 254,163 & 348,529 & $-94,366$ & 187,536 & 230,030 & $-42,494$ \\
\hline
\end{tabular}

Source: authors, based on OECD Migration Statistics. 
the potential and the actual workers as well. The number of actual workers could be calculated on the basis of the OECD Migration Statistics, which gives information also about the employment rate of foreign-born workers by country. The loss in the ISCED 1 and 2 category is also relatively high in case of the actual workers, which indicates that there is a high demand for unskilled workers as well. Furthermore, at least 34,693 may be overqualified according to the DIOC data.

It is worth mentioning that the balance of gains and losses may have improved since 2016. Although we do not have suitable up-to-date information on the actual foreign-born workers, their registered numbers increased by $24 \%$ according to the National Employment Service. Furthermore, the national accounts of 2018 show a $30 \%$ increase for total wages of foreign-born workers. These statistics, however, include short term temporary jobs, since workers even from the non-EU-member Ukraine and Serbia may work without permission up to 90 days. According to the statistics of the Hungarian National Directorate-General for Aliens Policing, the number of workers from outside the EU, especially from populous Asian countries significantly increased in the past couple of years, the growth rate of the number of registered workers from outside the Union was almost $160 \%$ in 2017 . The Hungarian government expressed its intention to give further permissions for foreign workers while there is a labour shortage in any activity area.

As the DIOC database contains information on occupations of mobile workers, it is possible to compare it with the job vacancies, for which Eurostat provides detailed data. Table 4 shows this comparison for both the mobile workers and for the actual workers. The demand for elementary occupations is relatively high in Hungary, but Hungarian-born workers tend to take such jobs abroad. Similarly, the number of vacant jobs among professionals is even higher, while a lot of Hungarian workers have such jobs abroad. In principle, these data could point to a substitution effect, but since the ISCO-categories are too broad (one-digit level only), this cannot be concluded. In order to investigate this, more detailed data would be needed.

\subsection{Comparison with the other V4 countries}

The net loss is a general problem of the Central and Eastern economies. The potential and actual gains and losses have been calculated also for the three other Visegrád countries (Czechia, Poland and Slovakia), for the sake of comparison. The results are summarized in Table 5. It has to be noted that the number of those who were born in the former Czechoslovakia has been broken down proportionally with the population. Also, a net workforce-loss index has been calculated for all the four countries. This proxy indicator has been determined in such a way that the net losses in the different categories were distinguished by education level. The determination of weights is certainly discretional, we have applied 1,2, and 3 for the three different levels, respectively, just for the sake of comparison. The sum of the net (negative) balances have been divided by the population (2016) of the corresponding country, and the fraction has been multiplied by -100 .

Fig. 4 shows the comparison of this index calculated for both the potential and actual loss. Poland seems to have by far the highest loss among the V4 countries, and Hungary's position is better than that of Slovakia. The index reflects more or less the potential loss over the population. In case of Poland, this is 7\%, while the corresponding value of Hungary is just the half of it. The high loss of Poland is partly the consequence of the emigration in the last two decades of 
Table 4. Vacancies by occupations in Hungary, Hungarian mobile workers' occupational pattern in OECD countries, and foreign workers' occupational pattern in Hungary and abroad in 2015 (\%)

\begin{tabular}{|c|c|c|c|c|c|c|c|c|c|c|}
\hline & Managers & Professionals & $\begin{array}{c}\text { Technical } \\
\text { and } \\
\text { associate } \\
\text { professionals }\end{array}$ & $\begin{array}{l}\text { Clerical } \\
\text { support } \\
\text { workers }\end{array}$ & $\begin{array}{c}\text { Service } \\
\text { and } \\
\text { sales } \\
\text { workers }\end{array}$ & $\begin{array}{c}\text { Skilled } \\
\text { agricultural, } \\
\text { forestry and } \\
\text { fishery } \\
\text { workers }\end{array}$ & $\begin{array}{l}\text { Craft and } \\
\text { related } \\
\text { trades } \\
\text { workers }\end{array}$ & $\begin{array}{l}\text { Plant and } \\
\text { machine } \\
\text { operators }\end{array}$ & $\begin{array}{l}\text { Elementary } \\
\text { occupations }\end{array}$ & $\begin{array}{l}\text { Armed } \\
\text { forces }\end{array}$ \\
\hline ISCO & 1 & 2 & 3 & 4 & 5 & 6 & 7 & 8 & 9 & 0 \\
\hline $\begin{array}{l}\text { Distribution of } \\
\text { job } \\
\text { vacancies in } \\
\text { Hungary }\end{array}$ & $1.3 \%$ & $20.1 \%$ & $17.3 \%$ & $5.5 \%$ & $5.9 \%$ & $0.3 \%$ & $6.8 \%$ & $13.6 \%$ & $15.3 \%$ & $13.9 \%$ \\
\hline $\begin{array}{l}\text { Distribution of } \\
\text { Hungarians' } \\
\text { occupations } \\
\text { in foreign } \\
\text { OECD } \\
\text { countries }\end{array}$ & $4.4 \%$ & $16.8 \%$ & $10.6 \%$ & $7.8 \%$ & $15.8 \%$ & $1.7 \%$ & $12.9 \%$ & $8.5 \%$ & $21.3 \%$ & $0.2 \%$ \\
\hline $\begin{array}{l}\text { Distribution of } \\
\text { actually } \\
\text { working } \\
\text { Hungarians' } \\
\text { occupations } \\
\text { in foreign } \\
\text { OECD } \\
\text { countries }\end{array}$ & $4.4 \%$ & $16.8 \%$ & $10.5 \%$ & $7.8 \%$ & $15.8 \%$ & $1.7 \%$ & $12.9 \%$ & $8.5 \%$ & $21.4 \%$ & $0.2 \%$ \\
\hline $\begin{array}{l}\text { Distribution of } \\
\text { foreign born } \\
\text { workers' }\end{array}$ & $5.8 \%$ & $22.0 \%$ & $14.9 \%$ & $6.5 \%$ & $18.5 \%$ & $2.1 \%$ & $13.1 \%$ & $8.1 \%$ & $8.7 \%$ & $0.2 \%$ \\
\hline
\end{tabular}


Table 4. Continued

\begin{tabular}{|c|c|c|c|c|c|c|c|c|c|c|}
\hline & Managers & Professionals & $\begin{array}{l}\text { Technical } \\
\text { and } \\
\text { associate } \\
\text { professionals }\end{array}$ & $\begin{array}{l}\text { Clerical } \\
\text { support } \\
\text { workers }\end{array}$ & $\begin{array}{c}\text { Service } \\
\text { and } \\
\text { sales } \\
\text { workers }\end{array}$ & $\begin{array}{c}\text { Skilled } \\
\text { agricultural, } \\
\text { forestry and } \\
\text { fishery } \\
\text { workers }\end{array}$ & $\begin{array}{c}\text { Craft and } \\
\text { related } \\
\text { trades } \\
\text { workers }\end{array}$ & $\begin{array}{l}\text { Plant and } \\
\text { machine } \\
\text { operators }\end{array}$ & $\begin{array}{l}\text { Elementary } \\
\text { occupations }\end{array}$ & $\begin{array}{l}\text { Armed } \\
\text { forces }\end{array}$ \\
\hline \multicolumn{11}{|l|}{$\begin{array}{l}\text { occupations } \\
\text { in Hungary }\end{array}$} \\
\hline $\begin{array}{l}\text { Distribution of } \\
\text { actually } \\
\text { working } \\
\text { foreign born } \\
\text { workers' } \\
\text { occupations } \\
\text { in Hungary }\end{array}$ & $6.0 \%$ & $22.0 \%$ & $14.5 \%$ & $6.2 \%$ & $18.1 \%$ & $2.2 \%$ & $13.9 \%$ & $8.3 \%$ & $8.6 \%$ & $0.2 \%$ \\
\hline
\end{tabular}

Source: authors, based on OECD Migration Statistics and Eurostat. 
Table 5. Stock of losses and gains for Czechia, Poland, and Slovakia (2015-2016, workers)

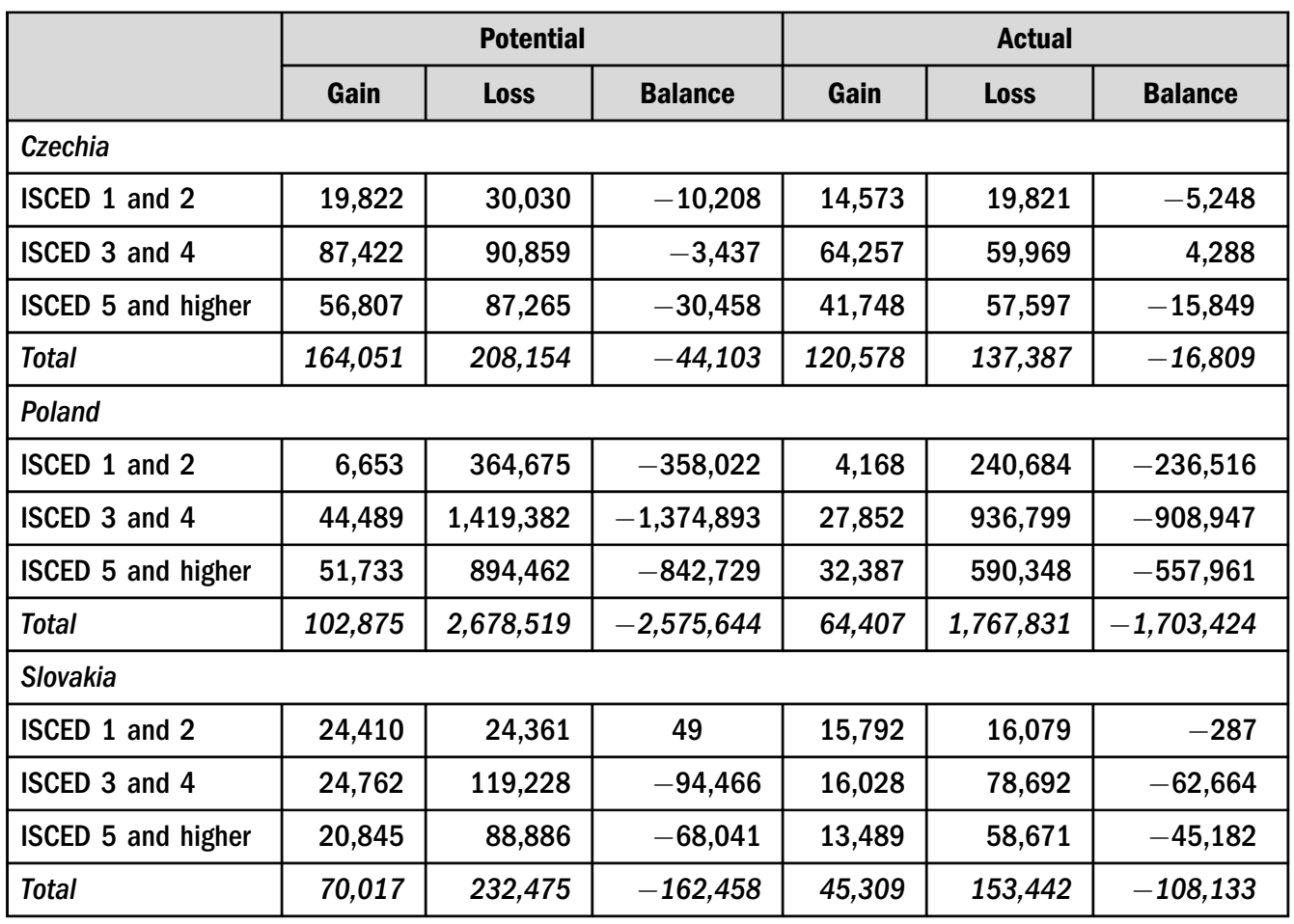

Source: authors, based on OECD Migration Statistics.

the 20th century, followed by the free movement within the EU. Poland's large negative balance is partly the result of their relative low gain: although the foreign-born population is large (for example, the share of Ukrainians is around 3\% of the population), their employment rate is low. The relatively good position of Czechia is due to its relatively well-developed economy; it may have a positive balance with the less developed Slovakia, worsening the Slovak position. As Tables 3 and 5 show, there is only one positive value in the column of balances: this is the balance of primary education in Slovakia, but its value is almost negligible. In case of Czechia and Hungary, the net loss is the highest in case of workers of tertiary education level, while the other two countries have losses primarily in the category of ISCED 3 and 4 (reflected also in the first part of the paper). This means that if the weights were set progressively with the educational attainment, the relative position of Czechia and Hungary would be worse. It would be worth including in the comparison also other economies in the region, such as Romania, Bulgaria and Croatia. As they are not OECD members, one cannot use the same database to calculate the losses and the proposed index. However, their population losses have been high in the past decade, which suggests very high workforce-losses. Since 1990 (the transition to a market economy), Bulgaria has lost around $18 \%$ of its population, while the population losses in Romania and Croatia have been 15 and 13\%, respectively, until 2016. The population of Hungary decreased by about $5 \%$ during the same period. 


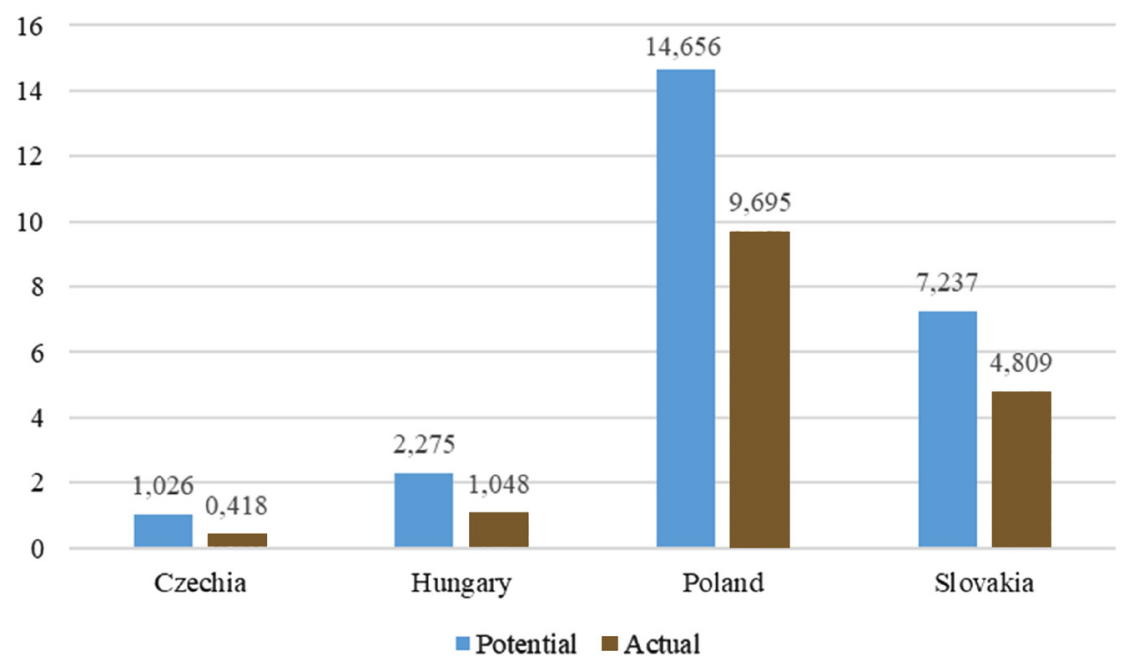

Fig. 4. Net workforce-loss index in the V4 countries. Source: authors

\section{CONCLUSIONS}

This article consisted of two parts. The first highlighted findings of a research project entitled "The social dimension of intra-EU mobility: Impact of public services". The research was conducted by Eurofound, an agency of the European Union which specialised in labour market and social policy issues. Although, as its title suggests, the project focused on the take-up of services and benefits by workers from the Central and Eastern Europe EU member states, in this article some key labour market-related aspects (relevant characteristics and labour market performance of these EU mobile citizens) were in focus.

This article has also supported the fact that labour market participation of the EU mobile citizens from the Central and Eastern European members states in the main host countries is usually high, and it has been steadily increasing during the years of recovery from the financial and economic crisis of 2008. In most countries, the employment rate of these citizens is above $70 \%$, and this is the case at the EU level as well (both if all the EU-28 countries are considered and also if only the EU-15). If aggregated at the EU level, their employment rate is higher than either that of the total, or that of the native population. In the UK, their employment rate is even higher than $80 \%$, again higher than both the total rate and rate for the native population.

Although the educational level of the EU-13 mobile citizens is high, they are employed mostly in low skilled jobs, where they are overrepresented in comparison with other groups, such as natives and other EU-15 mobile citizens. This shows difficulties with recognition of qualifications and also challenges of adequate labour market integration. At the same time, it also demonstrates that these mobile citizens have untapped potential. If this situation does not change in the near future, there is a risk of erosion of human capital even in the medium term. Therefore, it is important to monitor the evolution of skills matching. Furthermore, in order to facilitate better job/skill matches, the role of institutional/policy changes in this area should also 
be explored (e.g. more widespread recognition of qualifications and diplomas, role of employers, exploring good practice at company level, etc.).

Another important issue which requires further exploration are the specific features of women's participation and their role in the labour market in the different destination countries (also within the context of public services, e.g. elderly care, childcare, etc.). The Eurofound research project has shown the special case of Italy in this respect, and the consequences which dominance of that kind of employment may have had, for example high level of temporary employment of the EU mobile citizens compared to natives and third country nationals.

Although there are some signs of increasing wages in the sending countries, another interesting topic could be the issue of working conditions there, i.e. to what extent they play a role in increasing the outflow from these countries, whether they are a part of the push factors, and whether there is any improvement. Exploring the impact on sending countries is also an important research topic, primarily within the context of demographic changes in Europe. Whereas increased mobility could contribute to mitigating the consequences of population and workforce ageing in the host countries, more severe consequences could occur for ageing in the sending countries, even if remittances and accumulated pension entitlements could help in the future. Brain drain could adversely affect the sending countries, and even if mobility could provide an opportunity for intellectual (or know-how) remittances, there is a risk that "in the long-run, the benefits of intra-EU mobility for these countries will not be enough to compensate for a permanent brain drain" (CEPS - ASPEN 2018). It is a challenge, but at the same time, provides an even more forceful impetus for upward convergence of these countries.

The second part of the article analysed some impacts of intra-EU mobility on the labour market of Hungary. Although the outflow of Hungarian mobile workers may have supported dynamic wage increases, it also enhanced the longstanding problem of workforce loss. Labour shortage in several occupations and sectors appears to have stimulated growing immigration of third country nationals. It remains to be seen whether the growing inflow has a real substitution effect (more detailed data are required to draw a straightforward conclusion in this respect). It is clear, however, that this inflow is not enough to outweigh the loss, not to mention that from the sending countries' perspectives, it is understandable that they want to have a return from their tax payers' investment into education of their natives (see also Lutz et al. 2019). The OECD data on migration made it possible to provide a conservative estimate of the balance of workforce losses and gains. Also, an index of net workforce-loss has been proposed for cross-country comparison. Hungary's balance is relatively good compared to that of Slovakia and Poland. It is however significantly worse than that of Czechia, the better position of which is basically due to its relatively higher economic development level. Since only OECD data could be used, further research is needed to extend the cross-country comparison to the other eastern-European EU members, which are not members of the OECD.

\section{ACKNOWLEDGMENT}

This paper has been supported by the European Union and Hungary and co-financed by the European Social Fund through the project EFOP-3.6.2-16-2017-00017 entitled "Sustainable, intelligent and inclusive regional and city models". 


\section{REFERENCES}

Anghel, R. G. - Piracha, M., - Randazzo, T. (2015): Channelling Globalization. IZA Discussion Papers 9516. Azizi, S. (2019): The Impacts of Workers' Remittances on Poverty and Inequality in Developing Countries. Empirical Economics. https://doi.org/10.1007/s00181-019-01764-8.

Bénassy, J. P. - Brezis, E. S. (2013): Brain Drain and Development Traps. Journal of Development Economics 102: 15-22.

Botezat, A. - Ramos, R. (2020): Physicians' Brain Drain - A Gravity Model of Migration Flows. Globalization of Health 16: 7.

Brock, G. - Blake, M. (2015): Debating Brain Drain: May Government Restrict Emigration? Oxford: Oxford University Press.

CEPS - ASPEN (2018): Smart Strategies to Increase Prosperity and Limit Brain Drain in Central Europe. Summary of the Expert Conference, November, 2018.

Croix, D. - Docquier, F. (2012): Do Brain Drain and Poverty Result from Coordination Failures? Journal of Economic Growth 17: 1-26.

Dohlman, L. - DiMeglio, M. - Hajj, J. - Laudanski, K. (2019): Global Brain Drain: How Can the Maslow Theory of Motivation Improve Our Understanding of Physician Migration? International Journal of Environmental Research and Public Health 16: 7.

Eurofound (2015): Social Dimension of Intra-EU Mobility: Impact on Public Services. Luxembourg: Publications Office of the European Union.

European Commission (2018): Annual Report on Intra-EU labour mobility - 2017. Final report, January 2018. Brussels: European Commission.

Gheasi, M. - Nijkamp, P. (2017): A Brief Overview of International Migration Motives and Impacts, with Specific Reference to FDI. Economies 5(31): 1-11.

Golovics, J. (2019): A nemzetközi migráció mozgatórugói: elmélet és empíria - áttekintés [Driving Forces of International Migration: Theory and Empirics - An Overview]. Demográfia 62(1): 95-141.

Gödri, I. (2016a): Elvándorlási szándékok - álmok és konkrét tervek között. A migrációs potenciál jellemzői és meghatározó tényezői a 18-40 évesek körében Magyarországon [Migration intentions - between dreams and plans. Characteristics and Determinants of Migration Potential in the 18 to 40 Age Group in Hungary]. Hungarian Demographic Research Institute Research Report 98.

Gödri, I. (2016b): The Labour Market Integration of Immigrants in Hungary - An Analysis Based on Population Census Data. In: Blaskó, Z - Fazekas, K. (eds.): The Hungarian Labour Market 2016. Budapest: Institute of Economics, Centre for Economic and Regional Studies, Hungarian Academy of Sciences, pp. 122-136.

Grabowska, I. - Garapich, M. P. - Jazwinska, E. - Radziwinowiczówna, A. (2017): Migrants as Agents of Change: Social Remittances in an Enlarged European Union. Basingstoke: Palgrave Macmillan.

Hárs, Á. (2019): Increasing Outward Migration - Opportunities, Hopes and Labour Market Impacts. In: Tóth, I. G. (ed.): Hungarian Social Report, 2019. Budapest: TÁRKI.

Hárs, Á. - Simon, D. (2017): A külföldi munkavállalás és a munkaerőhiány [Working Abroad and the Shortage of Labour]. In: Fazekas, K. - Köllő, J. (eds): Munkaeröpiaci Tükör 2016. Budapest: Institute of Economics, Centre for Economic and Regional Studies, Hungarian Academy of Sciences, pp. 94-108.

Józsa, I. - Vinogradov, S. A. (2017): Main Motivation Factors of Hungarian Labor-migration in the European Union. Vadyba/Journal of Management 31(2): 47-52. 
Kullander, M. (2014): The Social Dimension of Intra-EU Mobility: Impact on Public Services - Country Study on Sweden. Unpublished manuscript. Dublin: Eurofound.

Lunde Rasmussen, C. - Kuhn, H-M. (2014): The Social Dimension of Intra-EU Mobility: Impact on Public Services - Country Study on Denmark. Unpublished manuscript. Dublin: Eurofound.

Lutz, W. - Amran, G. - Belanger, A. - Conte, A. - Gailey, N. - Ghio, D. - Grapsa, E. - Jensen, K. (2019):

Demographic Scenarios for the EU: Migration, Population and Education. Luxembourg: Publications

Office of the European Union.

Moreh, C. (2015): Magyar bevándorlók az Egyesült Királyságban: demográfiai, földrajzi és szociológiai körkép [Hungarian Migrants in the United Kingdom: Demographic, Geographic and Sociological Overview]. Demográfia 57(4): 137-172.

Okólski, M. (2012): Modernizing Impacts of Emigration. Studia Socjologiczne 3(206): 49-79.

Pires, A. J. G. (2015): Brain Drain and Brain Waste. Journal of Economic Development 40(1): 1-33.

Rapoport, H. (2017): Who is Afraid of the Brain Drain? A Development Economist's View. CEPII Policy Brief 14.

Saluja, S. - Rudolfson N. - Massenburg, B. B. - Meara, J. G. - Shrime, M. G. (2020): The Impact of Physician Migration on Mortality in Low and Middle- Income Countries: An Economic Modelling Study. BMJ Global Health 5(1): e001535.

Sandu, D. (2010): Modernising Romanian Society Through Temporary Work Abroad. In: Black, R. Engbersen, G. - Okólski, M. - Panţîru, C. (eds): A Continent Moving West? EU Enlargement and Labour Migration from Central and Eastern Europe. Amsterdam: Amsterdam University Press, pp. 271-288.

Wadsworth, J. (2017): Immigration and the UK Economy. LSE Centre for Economic Performance Election Analyses Series Paper EA039.

Open Access. This is an open-access article distributed under the terms of the Creative Commons Attribution 4.0 International License (https://creativecommons.org/licenses/by/4.0), which permits unrestricted use, distribution, and reproduction in any medium, provided the original author and source are credited, a link to the CC License is provided, and changes - if any - are indicated. 